\title{
HUBUNGAN LINGKUNGAN FISIK DAN KARAKTERISTIK KARYAWAN DENGAN PRODUKTIFITAS KERJA DI HOME INDUSTRI KERAJINAN GERABAH
}

Sepriana Urianti ${ }^{1 *}$, Bintang $\mathrm{H}$ Simbolon ${ }^{2}$

${ }^{1,2}$ Politeknik Kesehatan Kementerian Kesehatan Tanjungkarang

\section{Artikel Info :}

Received 6 Agutus 2020

Accepted 26 Aprl 2021

Available online 30 April 2021

\section{Editor: Imam Santosa}

Keyword :

Home industry, produktivity, physical environment, worker characteristics

\section{Kata kunci :}

Home industry, produktivitas, lingkungan fisik, karakteristik pekerja

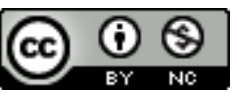

Ruwa Jurai: Jurnal

Kesehatan Lingkungan is

licensed under a Creative

Commons Attribution-

NonCommercial 4.0 International

License.

\begin{abstract}
A b stract
Pottery craft is a form of home industry that is being developed in Lampung Province. However, several industries show low productivity. This study aims to analyze the relationship between work productivity and physical environmental factors, and worker characteristics. This crosssectional study was carried out in four pottery-producing home industries involving 35 workers. Data collection was carried out by observation, measurement, and interviews. All data were analyzed using the SPSS 24.0 program. Chi-square test (alpha $=0.05$ ) was applied to determine the relationship of each physical environmental factor and worker characteristics with productivity. The results of the study found that most workers (77.1\%) were not productive. Physical environmental factors show a significant relationship with worker productivity, temperature $(p=0.003)$ and workspace lighting $(p=0.001)$. Age $(p=0.006)$ and work experience $(p=0.0001)$ showed a strong relationship with productivity. Environmental improvement is an urgent need to prevent health problems and increase productivity. On the other hand, it is necessary to increase the knowledge and skills of workers.
\end{abstract}

Kerajinan gerabah merupakan salah satu bentuk home industri yang sedang dikembangkan di Provinsi Lampung. Namun, beberapa industri menunjukkan produktivitas yang rendah. Penelitian bertujuan menganalisis hubungan produktivitas kerja dengan faktor lingkungan fisik dan karakteristik pekerja. Penelitian cross-sectional dilaksanakan di empat home industry penghasil gerabah dengan melibatkan 35 orang pekerja. Pengumpulan data dilakukan dengan observasi, pengukuran dan wawancara. Keseluruhan data dianalisis dengan program SPSS 24.0. Uji Chi-square $(a l p h a=0,05)$ diterapkan untuk mengetahui hubungan masing-masing faktor lingkungan fisik dan karakteristik pekerja dengan produktivitas. Hasil penelitian mendapatkan sebagian besar pekerja $(77,1 \%)$ tidak produktif. Faktor lingkungan fisik menunjukkan hubungan yang signifikan dengan produktivitas pekerja, yaitu iklim lingkungan kerja $(p=0,003)$ dan pencahayaan ruang kerja $(p=0,001)$. Umur $(p=0,006)$ dan pengalaman kerja $(p=0,0001)$ menunjukkan hubungan yang kuat dengan produktivitas. Perbaikan lingkungan menjadi kebutuhan mendesak untuk mencegah gangguan kesehatan dan meningkatkan meningkatkan produktivitas. Di sisi lain, dibutuhkan upaya peningkatan pengetahuan dan keterampilan pekerja.
${ }^{*}$ Corresponding Author: Sepriana Urianti

Politeknik Kesehatan Tanjungkarang

Jl. Soekarno-Hatta No 6, Bandar Lampung, Lampung. Indonesia

Email: seprianaurianti@poltekkes-tjk.ac.id

\section{PENDAHULUAN}

Home industry atau indutri rumah adalah usaha, baik produksi barang, jasa, kantor, atau bentuk kegiatan ekonomi lainnya yang dilakukan di tempat tinggal (Audina and Muhtadi, 2019; Handayani and Hati, 2018). Usaha adalah kegiatan yang dilakukan oleh seorang atau sekelompok orang ynag bertujuan menghasilkan barang atau jasa yang dibutuhkan oleh masyarakat dalam kehidupannya (Dewi and Windarto, 2019). Pembangunan sektor industri kecil mempunyai peranan penting dalam 
menciptakan kesempatan berusaha dan dapat menciptakan lapangan pekerjaan sehingga dapat meningkatkan perekonomian masyarakat setempat. Tenaga kerja yang dibutuhkan tentunya diharapkan mempunyai kualitas sumber daya manusia yang baik sesuai dengan keinginan pimpinan usaha (Handayani and Hati, 2018).

Saat ini, Provinsi Lampung memiliki lebih dari 460 industri, mulai industri kecil hingga industri besar dengan cakupan produktifitas yang berbeda-beda. Namun, berdasarkan data Dinas Tenaga Kerja Provinsi Lampung, terjadi penururnan produktivitas sebesar $10-15 \%$ setiap tahunnya, dan hanya sekitar 200 industri yang mampu mempertahankan tingkat produktifitasnya (Dinas Tenaga Kerja Provinsi Lampung, 2015).

Secara konseptual, sektor yang unggul memiliki daya saing yang tinggi, dan mencerminkan tingginya produktivitas sumber daya dalam menghasilkan satuan output, termasuk sumberdaya manusia. Sehingga, semakin tinggi daya saing maka akan semakin tinggi pula produktivitas sumber daya untuk menghasilkan produksi barang dan jasa (Bahtiar et al., 2018). Meningkatkan daya saing memerlukan perhatian terhadap hal-hal yang dapat meningkatkan produktifitas, seperti kualitas lingkungan kerja serta kualitas sumber daya pekerja (Wulansari, 2018).

Lingkungan kerja adalah tempat karyawan melakukan aktivitas setiap harinya. Lingkungan kerja yang baik akan memberikan rasa aman dan nyaman, sehingga karyawan dapat bekerja optimal. Selain lingkungan fisik, lingkungan kerja juga mencakup hubungan sosial antara sesama karyawan maupun antara bawahan dengan atasan (Susanti and Kristiawati, 2019). Lingkungan kerja yang menyenangkan, rekan kerja yang kooperatif, pimpinan yang memperhatikan karyawannya, kebijaksanaan yang memperhatikan karier serta kompensasi yang adil, akan meningkatkan kinerja karyawan yang pada akhirnya akan meningkatkan produktifitas kerja (Soedarmayanti, 2009).

Produktivitas kerja adalah perbandingan antara hasil yang diperoleh (output) dengan jumlah sumber daya yang digunakan sebagai masukan (input) (Anggraini, 2018; Kanajmi et al.,
2017; Wulansari, 2018). Produktivitas kerja merupakan kemampuan karyawan dalam berproduksi. Seorang karyawan dapat dikatakan produktif apabila mampu menghasilkan barang sesuai dengan yang diharapkan (target) dalam waktu yang yang telah ditetapkan. Produktivitas minimal (100\%), jika output yang dihasilkan sama dengan input yang digunakan (breakeven point) (Walukow et al., 2016).

Industri gerabah adalah industri yang mengolah bahan baku tanah liat menjadi barang fungsional atau seni. Salah satu sentra industri gerabah di Provinsi Lampung berada di Desa Negara Ratu, Kecamatan Natar, Kabupaten Lampung Selatan. Saat ini tercatat sebanyak enam home industri yang memproduksi gerabah. Hasil studi awal mendapatkan, sebanyak empat dari enam home industri memiliki produktivitas yang rendah, atau kurang dari $100 \%$. Target (output) pekerjaan yang harus diselesai adalah sepuluh pot guci berukuran sedang dari sekitar $70 \mathrm{~kg}$ bahan baku tanah liat per hari. Rendahnya produktivitas kerja diduga dipengaruhi oleh faktor lingkungan fisik dan karakteristik pekerja.

Penelitian bertujuan menganalisis hubungan produktivitas kerja dengan faktor lingkungan fisik dan karakteristik pekerja. Produktivitas kerja dihitung berdasarkan kemampuan setiap pekerja menyelesaikan target output. Lingkungan fisik meliputi iklim lingkungan kerja dan pencahayaan ruang kerja. Sedangkan karakteristik pekerja meliputi umur dan pengelaman kerja. Diharapkan hasil penelitian menjadi masukan bagi perusahaan dalam meningkatkan produktivitas pekerja, dan digunakan otoritas ketenagakerjaan dalam melakukan pembinaan usaha kecil dan mikro, termasuk home industry.

\section{BAHAN dan METODE}

Penelitian menggunakan rancangan crosssectional yang dilaksanakan di empat home industri penghasil gerabah di Desa Negara Ratu, Kecamatan Natar, Kabupaten Lampung Selatan. Populasi adalah seluruh karyawan di empat home industry yang berjumlah 35 orang, dan tidak dilakukan pengambilan sampel.

Pengumpulan data dilakukan dengan observasi, pengukuran dan wawancara. Observasi dilakukan untuk menilai produktivitas 
pekerja dengan membandingkan hasil kerja dengan target yang telah ditetapkan perusahaan. Dinyatakan produktif jika mampu menyelesaikan sepuluh pot guci berukuran sedang dari sekitar $70 \mathrm{~kg}$ bahan baku tanah liat per hari. Wawancara dilakukan kepada setiap pekerja untuk mengetahui umur dan pengelaman kerja.

Dua faktor fisik lingkungan kerja diukur, yaitu suhu/iklim lingkungan kerja dan pencahayaan lingkungan kerja. Terdapat lima tahapan pengukuran iklim lingkungan kerja (Kemenkes RI, 2016) yaitu : 1) melakukan pengukuran iklim lingkungan kerja; 2) melakukan koreksi hasil pengukuran iklim lingkungan kerja dengan pakaian kerja; 3) menentukan beban kerja berdasarkan laju metabolik; 4) menentukan alokasi waktu kerja dan istirahat dalam satu siklus kerja (work-rest regimen; 5) menetapkan nilai $N A B$ yang sesuai.

Pada penelitian ini, nilai koreksi pakaian kerja sama dengan nol (menggunakan pakaian kerja biasa), dan kategori laju metabolik masuk dalam tingkatan sedang (300). Perhitungan Nilai Ambang Batas (NAB) dilakukan pada setiap orang dengan memperhatikan berat badan. Iklim lingkungan kerja dinyatakan memenuhi syarat jika berada dibawah $N A B$, dan dinyatakan tidak memenuhi syarat jika melebihi NAB. Pencahayaan lingkungan kerja diukur dengan luxmeter. Penerangan lingkungan kerja industri keramik dinyatakan memenuhi syarat jika hasil ukur $\geq 300$ lux, dan dinyatakan tidak memenuhi syarat jika < 300 lux (Kemenkes RI, 2016).

Analisis data dilakukan dengan program SPSS 24.0. Analisis univariat dengan frekwensi dan proporsi digunakan untuk mendapatkan gambaran setiap variabel penelitian. Analisis bivariate dengan uji Chi-square (alpha $=0,05$ ) untuk mengetahui hubungan masing-masing faktor lingkungan fisik dan karakteristik pekerja dengan produktivitas. Pernyataan persetujuan (Ethical clearance) diperoleh dari Komisi Etik Penelitian Kesehatan (KEPK) Politeknik Kesehatan Tanjungkarang, dengan nomor 269/EA/KEPK-TJK/IX/2019.

\section{HASIL}

Hasil penelitian mendapatkan (Tabel 1), sebanyak $77,1 \%$ pekerja tidak dapat memenuhi target output yang ditetapkan, atau tidak produktif. Karakteristik pekerja menunjukkan bahwa kelompok yang tidak produktif adalah pekerja yang beruumur $\leq 16$ tahun $(14,3 \%)$ dan memiliki pengalaman kerja di industri gerabah < 3 tahun (20\%).

Tabel 1. Distribusi variabel penelitian

\begin{tabular}{lll}
\hline Variabel & Frekuensi & $\begin{array}{l}\text { Presentas } \\
\text { e }\end{array}$ \\
\hline $\begin{array}{l}\text { Produktifitas kerja } \\
\text { Tidak Produktif }\end{array}$ & 27 & 77,1 \\
$\quad \begin{array}{l}\text { Produktif } \\
\text { Iklim lingkungan kerja }\end{array}$ & 8 & 22,9 \\
$\quad$ Tidak memenuhi syarat & 28 & 80,0 \\
$\quad$ Memenuhi syarat & 7 & 20,0 \\
$\begin{array}{l}\text { Pencahayaan ruangan } \\
\text { Tidak memenuhi syarat }\end{array}$ & 31 & 88,6 \\
$\quad$ Memenuhi syarat & 4 & 11,4 \\
$\begin{array}{l}\text { Umur } \\
\text { Umur } \leq 16 \text { Tahun }\end{array}$ & 5 & 14,3 \\
Umur > 16 Tahun & 30 & 85,7 \\
Pengalaman kerja & & \\
$\quad$ 3 tahun & 7 & 20,0 \\
$\geq 3$ tahun & 28 & 80,0 \\
\hline
\end{tabular}

Hasil pengukuran kualitas lingkungan kerja mendapatkan sebanyak $80,0 \%$ pekerja melakukan aktifitasnya pada iklim lingkungan kerja yang tidak memenuhi syarat, yaitu diatas $30^{\circ} \mathrm{C}$. Sebanyak $88,6 \%$ bekerja dengan pencahayaan kurang dari 300 lux.

Analisis hubungan dengan Chi-square (alpha $=0,05)$ dilakukan untuk mengetahui hubungan hubungan masing-masing faktor lingkungan fisik dan karakteristik pekerja dengan produktivitas. Berdasarkan Tabel 2, terlihat bahwa sebagian besar pekerja yang tidak produktif, bekerja pada iklim lingkungan kerja $(89,0 \%)$ yang tidak memenuhi syarat kesehatan. Uji statistik menunjukkan hubungan yang signifikan antara iklim lingkungan kerja dengan produktifitas kerja ( $p$-value $=0,003$ ).

Pada variabel pencahayaan, terlihat bahwa sebagian besar pekerja (87,0\%) melakukan aktivitasnya pada ruangan yang intensitasnya kurang dari 300 lux. Fishes-exact test diterapkan karena terdapat sel kosong pada pengujian. Hasil menunjukkan hubungan yang signifikan antara pencahayaan lingkungan kerja dengan produktifitas kerja ( $p$-value $=0,001$ ).

Tabel 2 menunjukkan bahwa mayoritas pekerja yang tidak produktif berumur di atas 16 tahun 
(87,5\%), dan memiliki pengalaman kerja selama lebih dari 3 tahun (92,0\%). Ui chi-square menunjukkan hubungan yang bermakna antara umur ( $p$-value $=0,006)$ dan masa kerja ( $p$ value $=0,0001)$ dengan produktivitas.

Tabel 2. Hubungan Faktor Lingkungan Fisik dan Karakteristik Pekerja Dengan Produktifitas

\begin{tabular}{llllll}
\hline \multirow{2}{*}{ Variabel } & \multicolumn{2}{l}{ Tidak Produktif } & \multicolumn{2}{l}{ Produktif } & \multirow{2}{*}{-value } \\
\hline Iklim lingkungan kerja & $\mathrm{n}$ & $\%$ & $\mathrm{n}$ & $\%$ & \\
$\quad$ Tidak memenuhi syarat & 25 & 89,0 & 3 & 10,7 & 0,003 \\
$\quad$ Memenuhi syarat & 2 & 28,6 & 5 & 71,4 & \\
$\begin{array}{l}\text { Pencahayaan ruangan } \\
\quad \text { Tidak memenuhi syarat }\end{array}$ & 27 & 87,0 & 4 & 13,0 & 0,001 \\
$\quad$ Memenuhi syarat & 0 & 0,0 & 4 & 100 & \\
Umur & 1 & 20,0 & 4 & 80,0 & 0,006 \\
$\quad$ Umur $\leq 16$ Tahun & 26 & 87,0 & 4 & 13,0 & \\
$\quad$ Umur > 16 Tahun & 1 & 14,0 & 6 & 86,0 & 0,0001 \\
$\begin{array}{l}\text { Pengalaman Kerja } \\
\quad<3 \text { tahun }\end{array}$ & 26 & 92,0 & 2 & 8,0 & \\
$\quad \geq 3$ tahun & & & & & \\
\hline
\end{tabular}

\section{PEMBAHASAN}

Produktivitas kerja merupakan ukuran perbandingan antara hasil produksi dengan sumber daya yang digunakan (Anggraini, 2018; Kanajmi et al., 2017; Wulansari, 2018). Secara sederhana dinyatakan sebagai kemampuan karyawan dalam berproduksi (Walukow et al., 2016). Hasil penelitian mendapatkan $77,1 \%$ pekerja memiliki produktivitas yang rendah, karena tidak mampu mencapai target pekerjaan yang ditetapkan, yaitu sepuluh pot guci berukuran sedang per hari. Menurut Walukow, et al, seorang karyawan dikatakan produktif jika mampu menghasilkan barang sesuai dengan yang diharapkan (target) dalam waktu yang yang telah ditetapkan (Walukow et al., 2016).

Iklim lingkungan kerja adalah temperatur di ruang produksi gerabah. Penelitian mendapatkan (Tabel 2) bahwa mayoritas pekerja melakukan aktivitasnya pada iklim lingkungan kerja yang tidak memenuhi syarat kesehatan, dan berkaitan dengan produktivitas kerja. Suhu tinggi di ruangan kerja, biasanya berasal dari proses produksi yang memerlukan suhu tinggi (seperti proses peleburan dan pembakaran), atau peralatan yang menghasilkan panas (seperti generator dan ketel uap). Energi panas masuk lingkungan tempat kerja melalui pancaran langsung dari sumber panas atau merambat melalui permukaan (Handayani and Hati, 2018; Soeripto, 2008).

Panas berlebih dapat berpengaruh buruk terhadap kesehatan (Soeripto, 2008), berupa penurunan kemampuan fisik dan mental (Anggraini, 2018; Setiawati, 2015; Wulansari, 2018). Pada jangka pendek, panas berlebih mengakibatkan dehidrasi, ketidaknyamanan, mengurangi konsentrasi dan akurasi. Sedangakan jangka panjang dan terus menerus, dapat menyebabkan kelainan kulit, heat cramps, heat exhaustion, heat syncope, heat stroke dan hiperpireksia (International Labour Organization, 2013). Paparan panas berlebihan di lingkungan kerja juga berkaitan dengan dislipidemia, penyakit kardiovaskular, pencernaan, bahkan kematian. Tekanan darah akan meningkat jika terpapar panas tinggi, dan mengalirkan lebih banyak darah ke kulit untuk mengeluarkan panas (Lestari et al., 2018).

Hasil penelitian ini sesuai dengan penelitian sebelumnya yang menyatakan hubungan yang signifikan antara suhu (iklim lingkungan kerja) dengan produktifitas kerja (Anggraini, 2018; Setiawati, 2015; Soedarmayanti, 2009; Wulansari, 2018). Pengaturan suhu ruangan kerja yang memenuhi syarat akan meningkatkan kenyamanan kerja, yang pada akhirnya akan meningkatkan produktivitas. Agar tubuh manusia berfungsi secara efisien, perlu untuk 
tetap berada dalam kisaran suhu normal (International Labour Organization, 2013). Lingkungan kerja yang nyaman dan menyenangkan akan meningkatkan kinerja karyawan yang pada akhirnya akan meningkatkan produktifitas kerja (Soedarmayanti, 2009).

Tabel 2 memperlihatkan hubungan yang bermakna antara penerangan pada ruangan kerja dengan produktivitas. Hasil penelitian ini mengkonfirmasi penelitian sebelumnya yang menyatakan hubungan antara intensitas pencahayaan dengan produktivitas kerja (Asmarini, 2018; Handayani and Hati, 2018; Wulansari, 2018). Pencahayaan berkaitan dengan kelelahan mata pekerja. Kemenkes mensyaratkan penerangan di ruang kerja sebesar 300 lux (Kemenkes RI, 2016).

Penerangan di setiap tempat kerja harus memenuhi syarat agar pekerjaan dapat dilakukan dengan baik. Penerangan yang sesuai sangat penting untuk peningkatan kualitas dan produktivitas kerja (Asmarini, 2018; International Labour Organization, 2013; Soedarmayanti, 2009). Bila penerangan kurang sesuai, maka pekerja terpaksa membungkuk untuk memfokuskan penglihatan mereka, sehingga menimbulkan ketidaknyamanan dan memperlambat pekerjaan. Dalam jangka panjang, dapat menyebabkan masalah pada punggung dan mata (International Labour Organization, 2013).

Dua variabel karakteristik pekerja menunjukkan hubungan bermakna dengan produktivitas, yaitu umur ( $p$-value $=0,006)$ dan masa kerja ( $p$-value $=0,0001)$. Hasil penelitian ini sejalan dengan penelitian sebelumnya yang menyatakan hubungan signifikan antara umur dan pengalaman kerja dengan produktifitas pekerja (Kanajmi et al., 2017; Kurnia, 2010; Wiguna, 2017). Usia dan pengalaman pekerja harus disesuaikan dengan jenis pekerjaan, menghindari rendahnya produktifitas kerja keryawan (Kanajmi et al., 2017; Kurnia, 2010; Manullang, 2008; Soedarmayanti, 2009; Wulansari, 2018). Salah satu upaya untuk meningkatkan produktivitas, biasanya perusahaan akan mempekerjakan karyawan yang memeliki pengalaman kerja dan berusia produktif (Husein, 2008; Kanajmi et al., 2017;
Manullang, 2008; Wulansari, 2018). Upaya pelatihan menjadi pilihan untuk meningkatkan pengetahuan dan keterampilan pekerja yang akan berdampak pada peningkatan produktivitas (Audina and Muhtadi, 2019; Kurnia, 2010; Soedarmayanti, 2009; Walukow et al., 2016).

\section{SIMPULAN}

Hasil penelitian mendapatkan sebagian besar pekerja $(77,1 \%)$ tidak produktif, terutama dipengaruhi oleh faktor lingkungan fisik yang tidak memenuhi syarat, yaitu iklim lingkungan kerja ( $p$-value $=0,003$ ) dan pencahayaan ruang kerja ( $p$-value $=0,001$ ). Perbaikan lingkungan menjadi kebutuhan mendesak untuk mencegah gangguan kesehatan dan meningkatkan kenyamanan pekerja yang pada akhirnya akan meningkatkan produktivitas. $\mathrm{Di}$ sisi lain, meningkatkan pengetahuan dan keterampilan pekerja harus dilakukan untuk meningkatkan produktivitas.

\section{DAFTAR PUSTAKA}

Anggraini, R., 2018. Hubungan Tekanan Panas Dengan Produktifitas Kerja Pada Siswa Unit Produksi SMK Katolik St Mikael Surakarta Jawa Tengah.

Asmarini, W.R., 2018. Intensitas Pencahayaan Dengan Kelelahan Mata Yang Dialami Pembaca Di Ruang Baca Dinas Perpustakaan Dan Kearsipan Daerah Provinsi Lampung Tahun 2018.

Audina, S.F., Muhtadi, M., 2019. Strategi Keberhasilan Usaha Home Industry Sepatu Dalam Memberdayakan Masyarakat. Jurnal Agribisnis Terpadu 12, 120.

Bahtiar, J., Tumbuan, W.J.F.., Trang, I., 2018. Pengaruh Insentif, Kepuasan Kerja Dan Daya Saing Terhadap Produktivitas Kerja Karyawan Pada Ud. Jepara Karya Furniture, Kec Tuminting. Jurnal EMBA: Jurnal Riset Ekonomi, Manajemen, Bisnis dan Akuntansi 6, 638-647.

Dewi, S.M., Windarto, A.P., 2019. Analisis Metode Electre Pada Pemilihan Usaha Kecil Home Industry Yang Tepat Bagi Mahasiswa. SISTEMASI 8, 377.

Dinas Tenaga Kerja Provinsi Lampung, 2015. Profil Ketenagakerjaan. Bandar Lampung.

Handayani, W.N., Hati, S.W., 2018. Pengaruh Lingkungan Kerja Fisik Terhadap Produktivitas 
Kerja Karyawan Operator Bagian Produksipada Perusahaan Manufaktur Di Pt Abc Batam. Jurnal Aplikasi Administrasi 21, 9-30.

Husein, U., 2008. Desain Penelitian MSDM Dan Perilaku Karyawan. Rajawali Pers, Jakarta.

International Labour Organization, 2013. Keselamatan dan Kesehatan Kerja: Sarana dan Produktivitas, 1st ed, Handbook of Institutional Approaches to International Business. International Labour Organization, Indonesia.

Kanajmi, H., Zuki, M., Uker, D., 2017. Hubungan Umur Dan Pengalaman Kerja Dengan Kelelahan Dan Produktivitas Pemanenan Kelapa Sawit. Agroindustri 7, 44-55.

Kemenkes RI, 2016. Peraturan Menteri Kesehatan Republik Indonesia Nomor 70 Tahun 2016 Tentang Standar dan Persyaratan Kesehatan Lingkungan Kerja Industri, Kemenkes RI. Indonesia.

Kurnia, A.N., 2010. Pengaruh pengalaman, pendidikan dan usia terhadap produktivitas tenaga kerja di spbu ngembat padas gemolong sragen. Universitas Muhammadiyah Surakarta.

Lestari, D.T., Raharjo, M., Yunita, N.A., 2018.

Hubungan Paparan Panas Dengan Tekanan Darah Pada Pekerja Pabrik Baja Lembaran Panas. Jurnal Kesehatan Masyarakat (e-Journal) 6, 79-86.

Manullang, 2008. Dasar-Dasar Manajemen. Ghalia Indo, Yogyakarta.
Setiawati, G., 2015. Faktor-Faktor Yang Berhubungan Dengan Lingkungan Kerja Dalam Pencapaian Produktifitas Kerja Di Perusahaan Keripik Singkong Di Kabupaten Way Kanan. Soedarmayanti, 2009. Sumber Daya Manusia dan Produktivitas Kerja. Penerbit Mandar Maju, Bandung.

Soeripto, M., 2008. Hygiene Industri. Balai Penerbit FK UI, Jakarta.

Susanti, I., Kristiawati, I., 2019. Pengaruh Lingkungan Kerja, Pelatihan Dan Kualitas Produk Terhadap Produktivitas Karyawan Home Industry (Konveksi Kerudung) Di Vila Collection Laren Lamongan. Ecobisma: Jurnal Ekonomi, Bisnis dan Manajemen 6, 26-36.

Walukow, M.T., Roring, M., Tampi, J.R.., 2016. Pengaruh Pelatihan Sumber Daya Manusia Terhadap Produktivitas Kerja Karyawan Pada Pt Pln (Persero) Wilayah Suluttenggo Area Manado. Jurnal Administrasi Bisnis (Jab) 4, 1-9.

Wiguna, R.W., 2017. Faktor-Faktor Yang Mempengaruhi Produktifitas Pada Industri Kerajinan Genteng Di Kabupaten Klaten. Universitas Sunan Kalijaga, Yogyakarta.

Wulansari, R.T., 2018. Hubungan Faktor Internal Dan Lingkungan Dengan Produktifitas Kerja Home Industri Tahu Tempe Kecamatan Seputih Surabaya Kabupaten Lampung Tengah. Politeknik Kesehatan Tanjungkarang, Bandar Lampung. 